Quality : Jurnal Kesehatan

Volume 14, Nomor 2 Tahun 2020

pISSN : 1978-4325, eISSN : 2655-2434, DOI: 10.36082/qjk.v14i2.112

\title{
ANALISIS KEBIJAKAN GLOBAL TRAVEL WARNING SELAMA PANDEMI COVID-19 DAN IMPLEMENTASINYA DI INDONESIA
}

\begin{tabular}{|c|c|}
\hline \multicolumn{2}{|r|}{$\begin{array}{c}\text { Fathia Maulida }{ }^{1} \text {, Ina Rahayu Ginting }{ }^{2} \text {, Ita Ainy Ulfah }{ }^{3}, \text { Nur Khotimah Elfiyani }^{4} \text {, } \\
\text { Pundra Dara }{ }^{5} \text {, dan Hadi Pratomo } \\
\text { 1,2,3} \text { Fakultas Kesehatan Masyarakat, Universitas Indonesia } \\
{ }^{4,5,6} \text { Departemen Pendidikan Kesehatan dan Ilmu Perilaku,Universitas Indonesia }\end{array}$} \\
\hline Info Artikel & Abstrak \\
\hline $\begin{array}{l}\text { Genesis Naskah: } \\
\text { Submitted: } 01-07- \\
2020 \\
\text { Revised: } 23-09-2020 \\
\text { Accepted: } 1-12-2020\end{array}$ & $\begin{array}{l}\text { Covid-19 adalah penyakit pernapasan bawah yang disebabkan oleh virus yang disebut coronavirus yang } \\
\text { ditentukan sebagai darurat dalam Kesehatan Masyarakat oleh banyak negara termasuk Indonesia. Pada } \\
\text { tanggal } 27 \text { Januari } 2020 \text { WHO mengeluarkan rekomendasi kebijakan berupa travel warning yang dibuat } \\
\text { sebagai aturan-aturan bepergian ke berbagai negara untuk publik selama masa pandemi Covid-19. Di } \\
\text { Indonesia, travel warning ini belum pernah dievaluasi. Penelitian ini mengggunakan desain RAP dan } \\
\text { pendekatan penelitian kualitatif. Wawancara semi-terstruktur dilakukan dengan } 3 \text { informan yang }\end{array}$ \\
\hline $\begin{array}{l}\text { Kata Kunci: } \\
\text { Kebijakan, Travel } \\
\text { Warning, Pandemi, } \\
\text { COVID-19, } \\
\text { Implementasi }\end{array}$ & $\begin{array}{l}\text { melakukan perjalanan ke berbagai negara selama pandemi Covid-19 (sebagai Traveller) dan } 1 \text { sebagai } \\
\text { Stakeholder menggunakan aplikasi Zoom (teleconference video) yang dilakukan selama } 12 \text { hari }(1-12 \\
\text { Mei 2020). Data yang dihasilkan dibuat transkrip, dibuat matriks data serta disusun kategori dan } \\
\text { identifikasi tema-tema. Selanjutnya, data dianalisis menggunakan analisis konten berdasarkan analisis } \\
\text { persepsi informan dalam memberikan pendapat dan pengalaman mengenai kebijakan travel warning } \\
\text { WHO. Hasil penelitian ini menunjukkan bahwa di Indonesia implementasi Travel Warning (WHO) } \\
\text { mengenai protokol masuk wilayah regional belum sepenuhnya dilaksanakan di semua bandara. Selain itu, } \\
\text { kegiatan PSBB perlu ditingkatkan terkait ketegasan dan konsistensi pemerintah khususnya dalam } \\
\text { menjatuhkan sanksi kepada mereka yang melanggarnya. Untuk memutus rantai transmisi Covid-19 } \\
\text { disarankan penguatan partisipasi semua sektor mulai dari pemerintah serta masyarakat. }\end{array}$ \\
\hline
\end{tabular}

ANALYSIS OF THE GLOBAL TRA VEL WARNING POLICY DURING THE COVID-19 PANDEMIC
AND ITS IMPLEMENTATION IN INDONESIA

Keywords:

Policy, Travel

Warning, Pandemic,

COVID-19,

Implementation

\begin{tabular}{l} 
Abstract \\
\hline Covid-19 is a low respiratory disease caused by coronavirus as an emergency in Public Health by many \\
countries including Indonesia. WHO recommends Travel Warning on 27 January 2020, which was made \\
as a rule for travelling to various countries for the Covid-19 public pandemic.This research uses RAP \\
design and qualitative research approaches. Semi-structured interviews were conducted with 3 informants \\
who traveled to various countries during the Covid-19 pandemic (as a Traveler) and 1 as a Stakeholder \\
using the Zoom application (teleconference video) application which was conducted over 12 days (1 - 12 \\
May 2020). The resulting data is transcribed, the data matrix is made and categories and identification \\
of themes are arranged. Furthermore, the data were analyzed using content analysis based on the analysis \\
of informants' perceptions in providing opinions and experiences regarding WHO travel warning policy. \\
The results of this study indicate that in Indonesia the implementation of Travel Warning (WHO) \\
regarding regional entry protocols has not been fully implemented at all airports. In addition, PSBB \\
activities also need to be enhanced by the government's firmness and consistency, as well as efforts to \\
impose sanctions on those who violate them. The participation of all sectors starting from the government \\
and also the role of the community is needed to break the transmission chain of Covid-19.
\end{tabular}

Korespondensi Penulis:

Hadi Pratomo

Pondok Cina Kota Depok, Jawa Barat 12345

Email:pratomohadi@gmail.com

(C) Poltekkes Kemenkes Jakarta I

J1. Wijaya Kusuma No. 47-48 Cilandak Jakarta Selatan, Indonesia

email: jurnalquality@poltekkesjakarta1.ac.id
ISSN 2655-2434

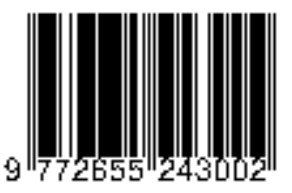




\section{Pendahuluan}

Covid-19 adalah merupakan penyakit pernapasan ringan hingga berat yang disebabkan oleh virus bernama SARS-CoV-2. Penyakit ini ditularkan melalui droplet penderita. Gejala penyakit ditandai terutama oleh demam, batuk dan sesak napas dan dapat menjadi penumonia dan berakhir gagal napas (Susilo, 2020). Sebagai tanggapan atas kejadian ini, Travel Warning WHO dibuat sebagai rekomendasi dan anjuran dalam melakukan perjalanan selama masa pandemi Covid19 ke berbagai negara bagi masyarakat. Menjelaskan bagaimana kebijakan-kebijakan yang harus dijalani oleh traveller ketika melakukan perjalanan selama masa pandemi ini (WHO,2020).

Travel Warning yang dikeluarkan oleh WHO merupakan kebijakan yang harus dilakukan pada setiap negara. Namun dari informasi informan yang mengunjungi beberapa negara selama masa pandemi, masih terdapat beberapa negara yang belum menjalani Travel Warning dengan baik dan benar. Dalam penelitian kami, kami menjelaskan bagaimana bentuk Travel Warning yang dikeluarkan WHO dan menanyakan apakah Traveller sudah mengetahui mengenai hal tersebut. Penelitian kami secara khusus dilakukan di kalangan Traveller yang melakukan perjalanan selama masa pandemi Covid19. Tujuan dari peneltian ini adalah 1) menganalisis Travel Warning yang dikeluarkan oleh WHO 2) menganalisis kebijakan mengenai Travel Warning yang dikeluarkan dari Kementrian Kesehatan 3) Melihat persepsi dan pengalaman traveler mengenai kebijakan Travel Warning dan kesesuaiannya dengan Travel Warning yang dikeluarkan WHO 4) melihat persepsi stakeholder terhadap kebijakan Travel Warning dalam implementasinya di Indonesia.

\section{Metode}

Desain penelitian ini adalah Prosedur Penilaian Cepat/Rapid Assessement Procedures terhadap Persepsi Informan terhadap Kebijakan Global Travel Warning dan menggunakan pendekatan kualitatif dengan menggunakan analisis konten. RAP merupakan pendekatan yang dapat memberikan informasi tetapi dalam proses memperoleh informasi tersebut dapat mengubah situasi. Saat melakukan RAP, peneliti dapat

(C) Poltekkes Kemenkes Jakarta I

Jl. Wijaya Kusuma No. 47-48 Cilandak Jakarta Selatan, Indonesia email: jurnalquality@poltekkesjakarta1.ac.id melibatkan informan dan memberi mereka umpan balik (Pearson, 2014).

RAP merupakan salah satu metode untuk mengumpulkan dan menganalisis data kualitatif secara efisien dalam periode waktu yang relatif lebih singkat. Pendekatan ini dirancang untuk memberikan kedalaman pada pemahaman tentang peristiwa dan konteks yang sangat penting bagi pengembangan dan implementasi pendekatan yang lebih kuantitatif (cross-sectional atau longitudinal) serta melibatkan penggunaan kuesioner survei dan instrumen diagnostik (Palinkas and Zatzick, 2019).

Analisis konten adalah teknik penelitian kualitatif yang dalam pengaplikasiannya menunjukkan tiga pendekatan yaitu konvensional, terarah atau sumatif (Hsieh and Shannon, 2005). Ketiga pendekatan tersebut digunakan untuk menginterpretasikan makna dari isi data teks. Pada penelitian ini menggunakan pendekatan sumatif yang melibatkan perhitungan dan perbandingan, biasanya konten diikuti oleh penafsiran konteks yang mendasari yang pada penelitian ini terkait persepsi informan terhadap Kebijakan Global Travel Warning (Hsieh and Shannon, 2005). Informan dipilih dengan teknik pengambilan purposive sampling dengan menentukan kriteria informan sesuai dengan tujuan penelitian. Kriteria informan yang dipilih yaitu WNI telah sedang melakukan travelling ke luar negeri selama pandemic Covid-19 (Mukhsin, Mappigau and Tenriawaru, 2017). Setelah itu, wawancara semi-terstruktur dilakukan dengan 3 informan yang melakukan perjalanan ke berbagai negara selama pandemi Covid-19 (sebagai Traveller) dan 1 sebagai Stakeholder menggunakan aplikasi Zoom (teleconference video) yang dilakukan dari tanggal $1-12$ Mei 2020. Data yang dihasilkan adalah transkrip kata demi kata dan pendekatan analisis isi digunakan untuk reduksi, penamaan data, memperoleh data analitik dan menentukan kategori dan tema. Tim peneliti mentranskip kata demi kata dari hasil wawancara dengan informan dan kemudian hasilnya dikategorikan sesuai dengan tema dan sub tema yang sudah disepakati oleh tim peneliti. Setelah itu, tim peneliti menganalisis dan mensinkronisasikan serta membandingkan persepsi dari informan tersebut dengan kebijakan yang sudah dibuat oleh WHO per tema dan sub tema (Rahnama et al., 2012). Data di analisis menggunakan analisis konten

ISSN 2655-2434 
berdasarkan analisis persepsi informan dalam memberikan pendapat dan pengalaman mengenai kebijakan travel warning WHO. Kemudian hasil analisis disinkronisasikan untuk melihat pada bagian mana yang sudah sesuai dengan Travel Warning yang sudah dibuat oleh WHO sesuai dengan tema dan sub tema dari penelitian (Rahnama et al., 2012).

\section{Hasil}

Partisipan penelitian ini adalah 3 orang traveller yang melakukan perjalanan ke berbagai negara selama masa pandemi Covid-19 dan 1 orang stakeholder yang mengerti akan kebijakan travel warning di pintu masuk negara. Usia informan bervarian antara 29 dan 57 tahun. Semua informan berjenis kelamin wanita. Jenis kebijakan yang dibahas adalah kebijakan mengenai Travel Warning anjuran WHO terhadap sinkronisasinya di negaranegara di dunia dan Indonesia. Tujuan utama adalah untuk menemukan persepsi dan pengalaman traveller mengenai kebijakan Travel Warning dan kesesuaiannya dengan Travel Warning WHO. Pendekatan yang digunakan adalah analisis konten. Temuan penelitian ini membantu peneliti untuk mendeteksi lima tema utama seperti berikut: 1 . TEMA: kebijakan travel warning WHO - 2. TEMA: persepsi informan terhadap kebijakan travel warning WHO - 3. TEMA: kesesuaian travel warning WHO dengan negara lain - 4. TEMA: kesesuaian travel warning WHO dengan Indonesia - 5. Tema: persepsi kebijakan travel warning (Eropa, Afrika Utara, Jepang dan Arab Saudi).

\section{Tema 1 : Kebijakan travel warning WHO}

WHO mengeluarkan dokumen yang memberikan rekomendasi terbaru untuk lalu lintas internasional sehubungan dengan wabah COVID19 , mengingat situasi yang berkembang pesat dan menggantikan saran yang sudah diterbitkan pada 27 Januari 2020 (WHO, 2020). Kebijakan tersebut berisi rekomendasi yang diberikan WHO untuk lalu lintas internasional, rekomendasi umum untuk semua negara, rekomendasi untuk berpergian internasional bagi traveller dan rekomendasi setibanya traveller di titik masuk suatu negara.

Saat ini, menurut informan A1 sebagai stakeholder yang bekerja di KKP pelabuhan indonesia, Indonesia sudah membuat Protokol Pintu

(C) Poltekkes Kemenkes Jakarta I

Jl. Wijaya Kusuma No. 47-48 Cilandak Jakarta Selatan, Indonesia email: jurnalquality@poltekkesjakarta1.ac.id
Masuk Wilayah Indonesia (Bandara, Pelabuhan, PLBDN) yang sudah sesuai dengan Kebijakan Travel Warning yang dikeluarkan oleh WHO. Informan yang bekerja di KKP mengatakan bahwa travel warning yang dibuat oleh WHO memiliki kesamaan dengan management of ill travel at point of entry, seperti guidelines di WHO. Ketika ada traveller yang keluar atau masuk, pihak terkait melakukan wawancara atau interview yang sudah sesuai dengan guidelines dari WHO. Standar yang digunakan di setiap negara juga seharusnya juga sudah disesuaikan dengan standar dari WHO. Untuk Indonesia, sejauh ini, di pintu-pintu keluar masuk negara sudah mengaplikasikan sesuai dengan standar yang dikeluarkan WHO.

"Ini kita sama ya sama management of ill travel at point of entry, seperti guidelines di WHO jadi kita itu ada pertama planning implementasi terus ada interview ke traveller terus jadi kita, jadi guidelines WHO itu sebenarnya udah ditranslate ya kedalam bahasa indonesia oleh kemenkes dan sejauh ini kita mengaplikasikannya sesuai dengan guidelines dari WHO" (A1, usia 30 tahun, Stakeholder).

Kemudian untuk pengaplikasiannya di lapangan, menurut informan A1 sebagai stakeholder yang bekerja di KKP pelabuhan Indonesia sudah sama baik itu di bandara, pelabuhan maupun PLBDN di kota mana pun di Indonesia.

"Sama semuanya, semuanya sama standarnya sesuai sama standar WHO Jadi sama semuanya, mau di Medan, di Sulawesi sama semuanya kalau ada penerbangan atau pelayaran dari luar negeri ke Indonesia yang sifatnya traveller atau pekerja imigran atau ABK yang pulang ke Indonesia kita penerapannya sama sesuai standar WHO" (A1, usia 30 tahun, Stakeholder).

\section{TEMA 2 : Persepsi informan terhadap kebijakan travel warning $\mathrm{WHO}$}

Untuk tema ini, informan yang berasal dari 3 orang traveller yang melakukan perjalanan ke negara Jepang, Eropa, Afrika Utara dan Arab Saudi menyatakan bagaimana persepsinya terhadap kebijakan travel warning WHO, baiknya kebijakan tersebut dilaksanakan guna mengurangi penyebaran Covid-19. Informan B1 Traveller Eropa dan B2 Traveller ke Jepang sudah menerapkan kebijakan tersebut dengan baik namun menurut informan B3 ISSN 2655-2434

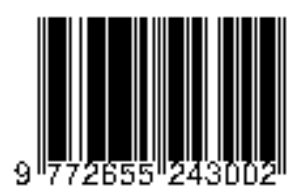


Traveller ke Arab Saudi masih belum melaksanakan kebijakan tersebut dengan baik.

Sedangkan menurut informan A1 sebagai stakeholder yang bekerja di KKP, kebijakan travel warning WHO sebenarnya sudah diterapkan, namun masih kurang dalam hal pemantauan.

\section{Pemahaman atau kejelasan travel warning yang dikeluarkan WHO}

Menyikapi apa yang informan ketahui mengenai isi dari kebijakan travel warning yang dikeluarkan WHO selama COVID-19, informan A1 Stakeholder, B1 Traveller ke Eropa, B2 Traveller ke Jepang dan B3 Traveller ke Arab Saudi memahami penjelasan dari travel warning WHO ini, mengenai isinya dan bagaimana aturan-aturan yang harus dijalankan selama masa pandemi ini ketika melakukan perjalanan. Isi dari travel warning menjelaskan bagaimana tata cara ketika di bandara, ketika berada di dalam pesawat, lalu bagaimana protokol yang harus di jalankan ketika keluar dan masuk suatu negara. Sesuai dengan pengalaman dalam melakukan perjalanan, maka informan B2 sebagai traveller ke Jepang memang memahami dan mempelajari terlebih dahulu mengenai travel warning WHO guna mencegah penularan dan penyebaran Covid-19 ketika melakukan perjalanan. Informan B2 memberi tanggapan sebagai berikut:

"Isi dari aturan tersebut memberikan informasi mengenai memakai masker, cuci tangan dengan langkah yang benar terutama sebelum menyentuh area wajah, menjaga etika batuk dengan benar, menjaga jarak dengan orang lain terutama orang yang menunjukkan gejala, menjaga pola hidup sehat" (B2, 35 tahun, traveller ke Jepang).

Hal ini sinkron dengan rekomendasi yang telah dikeluarkan oleh WHO yang merekomendasikan hal umum terkait kebersihan pribadi, etiket batuk dan menjaga jarak setidaknya satu meter dari orang yang menunjukkan gejala tetap sangat penting bagi semua wisatawan. Selain itu, lakukan kebersihan tangan sesering mungkin, tutupi hidung dan mulut Anda dengan siku tertekuk atau kertas tisu ketika batuk atau bersin dan segera buang tisu dan lakukan kebersihan tangan, jangan menyentuh mulut dan hidung dan penggunaan masker medis tidak diperlukan jika tidak menunjukkan gejala, karena tidak ada bukti bahwa

(C) Poltekkes Kemenkes Jakarta I

Jl. Wijaya Kusuma No. 47-48 Cilandak Jakarta Selatan, Indonesia email: jurnalquality@poltekkesjakarta1.ac.id memakai topeng - dari jenis apa pun - melindungi orang yang tidak sakit.

\section{Persepsi informan terhadap Kebijakan WHO} apakah bisa diaplikasikan di seluruh negara

Informan B2 sebagai traveler ke Jepang dan Informan B3 sebagai traveler ke Arab Saudi mengatakan bahwa kebijakan dari WHO sudah sangat mudah untuk dipahami dan dilakukan. Setidaknya setiap negara dapat mengikuti kebijakan tersebut dan menerapkannya di negaranya. Informan A1 (stakeholder) mengatakan bahwa terdapat formulir bernama Health Alert Card (HAC) yang dikeluarkan oleh WHO sebagai bentuk formulir yang harus diisi traveller ketika melakukan perjalanan. Setiap negara sudah menerapkan pemberian HAC kepada setiap traveller, namun karena terjadi penumpukan pada pintu masuk ketika pengumpulan HAC, maka sistem manual ini diganti menjadi aplikasi yang harus diunduh oleh setiap masyarakat agar dapat mengisi secara daring dan menghindari penumpukan masa yang dapat berisiko untuk penyebaran virus.

Namun, informan B1 sebagai traveler ke Eropa mengatakan beberapa peraturan sulit diterapkan di seluruh negara terutama dari segi perekonomian.

"Ada beberapa aturan yang tidak dapat dilakukan di negara-negara tertentu. Seperti pembatasan impor dan ekspor, untuk negara negara berkembang mungkin akan sulit jika ada pembatasan. Ditambah resikonya yang besar dari segi ekonomi" (B1, usia 29 tahun, traveller ke Eropa dan Afrika Utara).

Persepsi informan bagaimana seharusnya kebijakan tersebut diimplementasikan dalam suatu negara

Informan A1 (stakeholder), B2 (traveler ke Jepang) dan B3 (traveler ke Arab Saudi) menyatakan karena kebijakan ini dikeluarkan WHO untuk seluruh negara di dunia, maka seharusnya dilaksanakan oleh setiap pemerintah dalam suatu negara. Baik dari pemerintah pusat dan daerah pun harus bekerja sama untuk menerapkannya. Dan juga regulasinya harus kuat dan jelas, ketika suatu negara tidak memperbolehkan warganya untuk keluar dari negaranya, maka warga dari luar pun tidak dapat masuk ke negara itu sehingga harapan untuk 
menghentikan penyebaran virus benar-benar akan berhenti. Jangan dibiarkan peraturan yang sudah dibuat namun dijalankan dengan tidak adil dan merata.

Sedangkan menurut informan B1 (traveler ke Eropa dan Afrika Utara) masih terdapat beberapa negara yang sulit menerapkan rekomendasi kebijakan dari WHO terkait dengan perekonomian.

"Untuk peraturan lockdown yang diterapkan di Italia, mungkin belum tepat dilakukan di Indonesia, kerena Indonesia memiliki penduduk yang banyak, sehingga apabila diterapkan akan banyak kebutuhan dasar yang harus dipenuhi.'(B1, 29 tahun, traveler Eropa dan Afrika Utara)

\section{Kebijakan travel warning dari WHO tentang karantina setelah melakukan perjalanan dari negara pandemic covid-19}

Informan B1 (Traveler ke Eropa), B2 (Traveler ke Jepang), dan B3 (Traveler ke Arab Saudi) mengatakan bahwa kebijakan karantina sesuai dengan anjuran travel warning WHO, setelah seseorang melakukan perjalanan dari suatu negara diwajibkan untuk melakukan self-quarantine selama 14 hari untuk melihat masa inkubasi virus dan melihat apakah individu tersebut tertular Covid-19. Hal ini berlaku tidak hanya untuk penumpang yang melakukan perjalanan, tetapi juga berlaku pada awak atau petugas dari pesawat atau kapal. Hal ini disampaikan oleh informan sebagai berikut :

"Penting untuk melakukan self isolation selama 14 hari setelah melakukan perjalanan, karena harus dipantau juga kesehatannya apakah selama masa inkubasi timbul gejala atau tidak. Jangan sampai juga kita menyebarkan virus ke orang lain atau pembawa carrier" (B1, 29 tahun, traveller ke Eropa dan Afrika Utara).

Karantina yang dilakukan tidak hanya untuk penumpang namun juga untuk awak atau staff dari pesawat atau kapal yang telah melakukan perjalanan yang disarankan oleh WHO telah diterapkan dengan baik, berdasarkan pernyataan oleh informan A1 (stakeholder) :

"kalau petugas kapal atau traveller yang ada mengarah ke covid ke tanda dan gejala covid atau RDT nya positif itu langsung dirujuk ke wisma atlet nah sisanya yang masih sehat atau ODP itu karantina di kapal selama 14 hari ( $\mathrm{mm} \mathrm{mm}$ ) kalau di bandara di hotel kalau sekarang sih ga di hotel

(C) Poltekkes Kemenkes Jakarta I

Jl. Wijaya Kusuma No. 47-48 Cilandak Jakarta Selatan, Indonesia email: jurnalquality@poltekkesjakarta1.ac.id semua sih ada diklat diklat yang dipakai pemerintah untuk karantina untuk yang ODP ya, kalau yang PDP atau yang positif mengarah Covid dia ke wisma atlit" (A1, 30 tahun, Stakeholder).

Pendapat informan kebijakan travel warning mengenai skrining yang dilakukan di pintu-pintu masuk seperti bandara, pelabuhan atau daratan

Menurut paparan dari A1 (stakeholder) di Indonesia sudah dipersiapkan sarana dan prasarana untuk skrining di pintu masuk negara, seperti ruang pemeriksaan, termal scanner, tenaga medisnya, lembar anamnesa dan lain-lain.

"Traveller yang terjaring misalnya dia itu ODP, PDP atau OTG jadi itu nanti kita rapid dulu, terus kita koordinasi, implementasi deteksi dini itu kita sekarang kalau kemarin kemarin sih pake RDT kalau untuk deteksi dininya selain wawancara dan suhu tubuh itu pakai RDT tapi sekarang mengingat RDT sifatnya hanya skrining dan hasilnya banyak yang positif false atau negatif false jadi kita sekarang langsung ke PCR jadi kalau misalnya ada traveller atau kerja imigrans yang pulang ke Indonesia dengan gejala atau tanpa gejala tapi suhu badannya meningkat atau dengan gejala batuk pilek sesak seperti itu." (A1,30 tahun, stakeholder).

Sedangkan menurut informan B1 (traveler ke Eropa) dan B3 (traveler ke Arab Saudi) aturan dari WHO mengenai skrining sudah diterapkan namun hanya di beberapa bandara saja.

"Aturan dari WHO mengenai skrinning di pintu masuk bandara sebaiknya diterapkan di setiap bandara, karena pengalaman aku saat travelling selama masa pandemi ini. Hanya beberapa bandara saja yang menerapkan skrinning yaitu bandara di Marrakech, Roma dan Indonesia” (B1, 29 tahun, traveller ke Eropa dan Afrika Utara).

Pendapat lain menurut informan B2 (traveler ke Jepang) mengatakan skrining suhu hanya sebagai penapisan pertama, ia berpendapat bahwasannya dilakukan penutupan bandara lebih baik

"Perlu memang ya skrinning suhu tubuh. Tapi kan pada kenyataannya tidak semua yang kena Covod-19 itu punya demam atau mungkin Dia sudah melewati fase-fase demam itu. Jadi agak susah juga ya. Ya mungkin itu sebagai penapisan pertama boleh lah. Tapi tetep aja menurut Saya lebih baik tutup aja bandara nya. Jadi jika memang ingin dilaksanakan

ISSN 2655-2434 
lebih baik tegas aja. Tutup aja. Karena buktinya kebanyakan yang kena itu yang tanpa gejala." (B2, usia 35 tahun, traveller ke Jepang).

Hal ini tidak sesuai dengan rekomendasi WHO yang seharusnya travel warning ini diterapkan oleh semua bandara atau pintu masuk di semua negara. Karena hal yang dicantumkan di rekomendasi seperti skrining suhu tubuh akan mempengaruhi penyebaran dan penularan Covid-19 pada negara tersebut.

Pendapat informan kebijakan travel warning mengenai pembatasan melakukan perjalanan dan perdagangan pada negara-negara yang terkena pandemi

Informan A1 (stakeholder), B2 (traveler ke

Jepang), dan B3 (traveler ke Arab Saudi) menyatakan seharusnya memang dilakukan pembatasan penerbangan untuk mengurangi penyebaran virus. Tidak hanya melakukan pembatasan pada perjalanan manusia, tetapi juga melakukan pembatasan pada perdagangan dikarenakan jika tidak dilakukan pembatasan ditakutkan akan menjadi bom waktu untuk peningkatan kasus yang lebih besar lagi. Sedangkan informan B1 (traveler ke Eropa), kurang setuju karena mempengaruhi perekonomian suatu daerah.

"Untuk pembatasan melakukan perjalanan aku kurang setuju. Karena tempat tempat di eropa pendapatannya lebih banyak dari parawisata, café dan hotel. Sehingga jika ada pembatasan, maka akan terganggu dari segi ekonomi”. (B1, 29 tahun, traveler Eropa dan Afrika Utara)

Namun pada kenyataannya informan A1 mengatakan jika untuk perdagangan, mungkin pembatasan merupakan hal yang belum tepat dilakukan, dikarenakan pada masa pandemi ini semakin banyak kebutuhan yang harus dipenuhi baik dalam bentuk logistik, obat-obatan dan bahan kebutuhan lainnya.

Menurut informan A1, barang-barang seperti alat medis, makanan dan kebutuhan pokok lainnya, tidak dilakukan pembatasan dalam impor dan ekspornya ketika masuk ke suatu negara, karena hal tersebut merupakan kebutuhan pokok yang harus selalu tersedia.

"Kalau obat vaksin alkes barang import yang mendukung perekonomian itu tidak ada pembatasan”. (A1, usia 30 tahun, Stakeholder).

(C) Poltekkes Kemenkes Jakarta I

Jl. Wijaya Kusuma No. 47-48 Cilandak Jakarta Selatan, Indonesia email: jurnalquality@poltekkesjakarta1.ac.id
TEMA 3 : Kesesuaian travel warning WHO dengan negara lain

Rekomendasi untuk Lalu Lintas Internasional

Untuk lalu lintas internasional, informan A1

(stakeholder) menyatakan WHO telah mengeluarkan kebijakan yang harus diterapkan oleh seluruh negara. Health Alert Card (HAC) sudah diaplikasikan di seluruh negara dan digunakan di setiap pintu masuk negara. Travel warning WHO tidak hanya diberlakukan pada traveller saja tetapi untuk awak dan pekerja yang turut dalam perjalanan tersebut. Pengaplikasiannya di Indonesia sudah sesuai guideline dari WHO.

WHO menyatakan bahwa seharusnya dilakukan pembatasan penumpang yang melakukan perjalanan ke berbagai tempat atau negara agar mengurangi penyebaran virus Covid-19. Namun menurut informan B1 (traveler ke Eropa), pembatasan penumpang tersebut hanya pada beberapa negara saja, dengan kata lain belum semua negara yang menerapkan rekomendasi WHO tersebut.

"Tetapi di beberapa penerbangan yang saya lakukan tidak ada pembatasan mengenai jumlah penumpang. Baru dilakukan pembatasan penumpang itu dari milan ke oman, banyak penumpang yang diposisikan duduk sendiri di dalam pesawat. Tetapi dari Marrakech ke Roma itu masih full tempat duduknya. Dari Oman ke Jakarta itu penumpangnya padet, hanya saja kita yang dari Roma di upgrade ke business class. Mungkin karena kita riwayat perjalanan dari Italia" (B1, 29 tahun, traveller ke Eropa dan Afrika).

Sedangkan pendapat berbeda dari informan B2 (traveler ke Jepang) dan B3 (traveler ke Arab Saudi) menyatakan bahwa saat bepergian masih terdapat beberapa turis asing yang belum mengikuti peraturan yang direkomendasikan oleh WHO.

\section{Rekomendasi Umum untuk Semua Negara}

Informan A1 (stakeholder) menyatakan bahwa rekomendasi umum untuk semua negara adalah setiap traveller mengisi HAC setiap melakukan perjalanan.

"pengaplikasian health alert card (HAC) dari WHO sudah diberlakukan di seluruh dunia untuk diisi oleh seluruh traveller yang melakukan perjalanan" (A1,30 tahun, stakeholder).

ISSN 2655-2434 
Hal ini sesuai dengan rekomendasi dari WHO bahwa setiap Traveller atau Crew yang melakukan perjalanan harus mengisi Health Alert Card yang dikeluarkan.

Untuk rekomendasi dari WHO untuk hotel dan penginapan, menurut informan B1 (traveler Eropa), di Eropa sudah menjalankan travel warning WHO dan aturan-aturan yang harus dilaksanakan oleh pihak hotel dan penginapan. Hal-hal yang dilakukan seperti meminimalisir pertemuan antara pegawai hotel dan juga tamu.

"Ketika di Milan menginap di hotel, saya komunikasi dengan resepsionisnya tidak ketemu langsung. Kita saling kirim email. Dia email detail alamat, dan nanya aku check-in kapan. Lalu memberikan nomor kamar, lalu harus ambil kunci sendiri di meja resepsionis. Dan waktu check-out juga hanya kirim email dan tidak bertemu siapapun.Tetapi aku tidak tau karena emang hotelnya dari awal pelayanannya lewat email atau memang karena Covid-19 ini. Saat menaiki transportasi darat seperti bus dan kereta api, belum merasakan ada aturan physical distancing dari negara terkait. Karena waktu menaiki bus, tempat duduknya benar-benar full. Untuk kereta api tetap lumayan padet. Dan tidak ada skrinning saat menaiki bus dan kereta api" (B1, 29 tahun, traveller ke Eropa dan Afrika).

Lain halnya dengan informan B2 (traveler ke Jepang) menyatakan bahwa dalam pengalamannya di Jepang sudah mengikuti rekomendasi umum yang dikeluarkan seperti menutup beberapa toko yang akan menyebabkan keramaian atau mengumpulnya massa di satu tempat. Toko-toko sudah tutup pada jam yang sudah ditentukan guna mencegah penyebaran Covid-19.

"Sudah sesuai kalau menurut Saya ya. Karena pada saat Saya disana sekolah itu sudah diliburin. Kayak Disneyland itu sudah tutup dan pertokoan itu sudah tutup jam 8 malam. Sudah sesuai, mereka meminimalisir tempat-tempat ramai seperti Disneyland itu kan seluruh dunia turis pasti ke Disneyland" (B2, usia 35 tahun, traveler ke Jepang).

Sedangkan informan B3 (traveler ke Arab Saudi) menyatakan bahwa di Arab Saudi mulai diterapkan lockdown saat kembalinya ke Indonesia.

(C) Poltekkes Kemenkes Jakarta I

Jl. Wijaya Kusuma No. 47-48 Cilandak Jakarta Selatan, Indonesia email: jurnalquality@poltekkesjakarta1.ac.id

\section{Rekomendasi untuk Bepergian Internasional bagi Traveller}

Menurut informan A1 (stakeholder), B1 (traveler ke Eropa) dan B2 (traveler ke Jepang) selama bepergian, rekomendasi travel warning masih terlalu santai dilaksanakan. Belum terlihat pembatasan pada penumpang penerbangan dan di bandara belum terlihat adanya hand sanitizer disetiap sudutnya.

"Selama ku traveling, menurut ku aturan di beberapa negara yang aku kunjungi masih sangat santai. Mungkin karena saat itu kasus positif belum terlalu banyak. Kita terbang dari Jakarta-oman, Oman-frankfurt, Zurich-Barcelona, BarcelonaGranada, Granada-Marrakech, Marrakech-Roma, Milan-Oman, Oman-Jakarta. Tetapi saya tidak melihat hand sanitizer di bandara tersebut, hanya baru melihat disediakan hand sanitizer saat di Bandara di Indonesia" (B1, 29 tahun, traveller ke Eropa).

Informan B3 (traveler ke Arab Saudi) mengatakan bahwa kebijakan perjalanan bagi traveller malah belum dilaksanakan di Mekkah pada saat itu seperti berikut :

"Kebijakan ya sudah baik, tapi saat saya melakukan perjalanan itu belum terlaksana, baru ada saat saya balik dari Jeddah di Bandara Soeta. Untuk handsanitizer, masker, tidak disediakan di sana physical distancing pun belum ada, tapi karena saya dan anak sudah pakai masker setiba di sana, tapi orang-orang di sana sudah pakai masker, mungkin ada himbauan tapi karena keterbatasan bahasa sayanya yang tidak paham” (B3, usia 57 tahun, traveler ke Arab Saudi).

\section{Setibanya Traveller di Titik Masuk Suatu Negara}

Informan A1 (stakeholder) menyatakan setibanya Traveller di Titik Masuk suatu Negara, skrining suhu di titik masuk suatu negara mungkin tidak terlalu efektif karena kita bisa saja melewatkan pelancong yang masih berada dalam masa inkubasi penyakit atau pelancong yang menyembunyikan demam selama perjalanan atau mungkin adanya demam dari penyebab yang berbeda. Oleh karena itu disarankan untuk menyertai dengan: Pesan kesehatan, Kuesioner primer, Pengumpulan dan analisis data, Kasus yang dicurigai terdeteksi pada saat kedatangan, Personel terlatih untuk deteksi dini 
dan evaluasi awal kasus dan dilengkapi dengan persediaan yang diperlukan.

"kesiap-siagaan pihak bandara, pelabuhan dan daratan dalam menghadapi covid-19 seperti penyediaan hand sanitizier sudah ada disetiap sudut bandar atau pelabuhan. Untuk masker, jika ditemukan yang sakit tapi tidak menggunakan masker maka masker akan diberikan" (A1, 30 tahun, Stakeholder).

Informan B1 (traveler Eropa) menyatakan sesampainya di negara yang dikunjungi sudah langsung melakukan skrinning suhu tubuh dan dapat form kuning kesehatan (HAC) untuk diisi. Hal ini sinkron dengan rekomendasi yang telah dibuat oleh WHO.

"Pertama kali melakukan skrinning untuk Covid-19 itu justru waktu kita masuk ke Marocco. Jadi waktu di bandara Marocco dapet form kuning seperti surat kesehatan dan catatan perjalanan. Disitu ada pertanyaan tentang apakah kita mengalami batuk, sesak nafas, demam. Gejalagejala itu pertama kali di skrinningnya di Marocco. Tetapi hanya berupa mengumpulkan form kuning ke bagian immigrasi"'(B1, 29 tahun, traveler ke Eropa dan Afrika).

TEMA 4 : Persepsi informan terhadap kebijakan travel warning WHO (Kesesuaian travel warning WHO dengan Indonesia)

\section{Pemeriksaan/Skrining di Bandara Indonesia}

Berdasarkan hasil penelitian, informan A1 (stakeholder) mengatakan bahwa travel warning dari WHO sudah sesuai dengan yang diterapkan di Indonesia, karena kebijakan tersebut memang seharusnya dilaksanakan di setiap negara. Indonesia sudah menerapkan segala hal yang dianjurkan oleh WHO terkait di pintu masuk dan keluar negara, contohnya adalah pengisian HAC yang harus diisi oleh seluruh penumpang dan staf pekerja yang melakukan perjalanan.

WHO menyarankan untuk melakukan skrining di bandara dan pelabuhan internasional dengan tujuan deteksi dini wisatawan yang bergejala untuk evaluasi dan perawatan lebih lanjut, dan dengan demikian mencegah penyebaran virus COVID-19.

Menyikapi skrining yang dilakukan di bandara di Indonesia maka Informan B2 (traveler ke Jepang) yang berasal dari Indonesia yang

(C) Poltekkes Kemenkes Jakarta I

Jl. Wijaya Kusuma No. 47-48 Cilandak Jakarta Selatan, Indonesia email: jurnalquality@poltekkesjakarta1.ac.id berpergian ke Jepang yang menanggapi pemeriksaan yang dilakukan oleh pihak bandara di Indonesia sebagai berikut:

"Pada saat saya datang sudah sesuai ya. Jadi mereka sama isi form juga, periksa suhu juga. Hand sanitizer sudah disediakan dimana-mana ya. Skrining seperti pengecekan suhu dilakukan oleh petugas bandara" (B2, usia 35 tahun, traveler ke Jepang).

Tetapi menurut informan B3 (traveler ke Arab Saudi) yang berasal dari Indonesia yang berpergian ke Arab Saudi mengatakan bahwa skrinning yang di lakukan di Bandara di Indonesia belum maksimal. Hal ini yang ditanggapi oleh informan ini mengenai skrining yang di lakukan oleh pihak bandara di Indonesia:

"Nggak ada skrinnig apa-apa selain cek suhu" (B3, usia 57 tahun, traveler ke Arab Saudi)

Menurut informan B1 (traveler ke Eropa) selama dia melakukan perjalanan ke Eropa dan Afrika. Skrining di Bandara di Indonesia yang paling sesuai dengan aturan dari travel warning yang di keluarkan oleh WHO. Informan B1 menanggapi sebagai berikut:

"Di bandara Indonesia kita menulis kartu kuning (seperti pertanyaan apakah batuk,sesak,demam),surat yang menyatakan bahwa kita sehat, surat riwayat perjalanan. Selama traveling di Bandara di Indonesia pertama kali kita menumkan hand sanitizer. Jadi bandara yang meyediakan hand sanitizer itu baru di Indonesia. Selain itu, sudah ada deklarasi kesehatan, yaitu menyaring penumpang kemungkinan yang membawa virus Covid-19 ini dari luar. Lalu mengisi alamat,nomor $k t p$ dan nomor telepon untuk pemantauan" (B1, usia 29 tahun, traveller ke Eropa dan Afrika Utara).

\section{Karantina Mandiri (Self Isolation)}

Karantina dilakukan guna mencegah penyebaran dan penularan virus Covid-19 agar tidak tinggi. Informan yang telah melakukan perjalanan mengatakan telah melakukan karantina mandiri terhadap dirinya agar tidak menularkan ke orang lain ketika dia ternyata terinfeksi. Namun dikarenakan belum baiknya sosialisasi mengenai karantina ini ketika sampai di Indonesia, maka informan tidak

ISSN 2655-2434

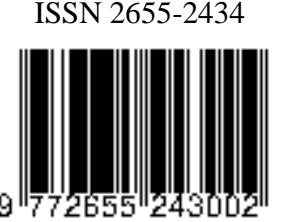


sepenuhnya benar dalam melakukan karantina mandiri sesuai dengan pernyataan informan B1 (traveler ke Eropa), B2 (travelerke Jepang), dan B3 (traveler ke Arab Saudi).

"Yang jelas diem di rumah dan memantau dan menjaga supaya kondisi kita tetap sehat. Di Bandara tidak ada anjuran untuk melakukan isolasi mandiri 14 hari. Hanya saya dengan kesadaran sendiri melakukan hal tersebut " (B2, 35 tahun, traveller Jepang).

"Aku baru tahu harus self isolation setelah 1 mingguan setelah aku pulang dari traveling. Aku kira 14 hari hanya pemantauan kondisi kesehatan. Jadi untuk self isolation aku belum melakukan. Karena aku masih menjalankan aktifitas seperti biasa. Aku tetap kerja dan ketemu teman. Itu tidak aku lakukan karena belum tau dan tidak mendapat informasi mengenai itu" (B1, 29 tahun, traveller Eropa dan Jepang).

\section{Physical Distancing di Indonesia}

Seperti yang terlihat, bahwa dalam pelaksanaan PSBB masih banyak warga yang tidak mematuhi peraturan ini. Pada sebagian aspek sudah baik dan efektif dilakukan seperti penutupan Mall dan bioskop atau tempat tempat keramaian. Namun karena adanya tuntutan ekonomi dan pekerjaan yang menekan, maka tidak banyak masyarakat yang mengabaikan peraturan PSBB ini dan tetap melakukan aktivitas seperti biasa sehingga tidak kala sering terjadi penumpukan masyarakat yang seharusnya tidak terjadi agar penyebaran virus tidak terjadi lebih cepat. Hal ini sesuai dengan pernyataan informan B2 (traveler ke Jepang) dan B3 (traveler ke Arab Saudi).

"Belum berjalan baik, warganya masih suka berkeliaran, pedang-pedagang masih berkerumunan, tapi memang factor ekonomi juga sih" (B3, 57 tahun, traveller ke Arab).

Dapat dilihat juga bahwa aturan PSBB ini dibuat namun belum ada sanksi terkait yang ada jika dilakukan pelanggaran, sehingga pemerintah terkesan tidak konsisten dalam membuat kebijakan. Dan ketidakkonsistenan ini menjadi alasan mengapa masih banyak masyarakat tidak patuh melakukan

(C) Poltekkes Kemenkes Jakarta I

Jl. Wijaya Kusuma No. 47-48 Cilandak Jakarta Selatan, Indonesia email: jurnalquality@poltekkesjakarta1.ac.id dalam penerapan PSBB ini. Hal ini sesuai dengan pernyataan informan B1 (traveler ke Eropa).

"Ketegasan dan konsistensinya pemerintah dalam aturan kebijakan yang dibuat, misalnya larangan mudik untuk daerah daerah yang memiliki kasus positive covid yang besar. Kota kota besar harus di perketat larangannya, jangan sampai kita membawa virus ke kampung halaman.Orang-orang tertentu misalnya pembinis masih diperbolehkan terbang, masih dibeda-bedakan aturannya" (B1, 29 tahun, traveller ke Eropa dan Afrika).

Sedangkan menurut informan A1 (stakeholder) memberikan tanggapan mengenai PSBB di Indonesia kebijakannya sudah sesuai namun masih perlu sosialisasi.

"Kalau saran atau pendapat, mungkin gini kan kalau misalnya PSBB ini ada sudah ada apa pedomannya untuk $R T, R W$ dan desa ya, harusnya kayak kader $R T R W$ desa itu lebih banyak mensosialisasikan untuk mereka aplikasi PSBB di lingkungan rumah mereka gitu jadi warganya memang harus patuh ke pemerintah pusat".

TEMA 5 : Persepsi Kebijakan Travel Warning (Eropa, Afrika Utara, Jepang dan Arab Saudi)

Negara-negara harus mengintensifkan pengawasan untuk wabah dan memantau dengan hati-hati evolusi wabah Covid-19 serta memperkuat pengawasan epidemiologis. Negara-negara harus terus meningkatkan kesadaran melalui komunikasi risiko yang efektif mengenai Covid-19 kepada masyarakat umum, profesional kesehatan, dan pembuat kebijakan, dan untuk menghindari tindakan yang mempromosikan stigma atau diskriminasi.

"Saat menaiki transportasi darat seperti bus dan kereta api, belum merasakan ada aturan physical distancing dari negara terkait. Karena waktu menaiki bus, tempat duduknya benar-benar full. Untuk kereta api tetap lumayan padet. Dan tidak ada skrinning saat menaiki bus dan kereta api” ", (B1, 29 tahun, traveller ke Eropa dan Afrika).

\section{Kesesuaian Travel Warning di Negara Lain, Dapat Diterapkan di Indonesia : Travel Warning di Negara Lain}

Menurut informan B1 (traveler ke Eropa), beberapa negara dan maskapai yang dikunjungi dan digunakan oleh informan sudah menjalani dan

ISSN 2655-2434

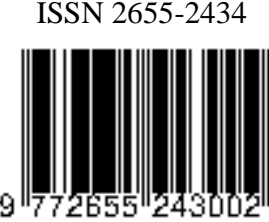


menerapkan travel warning oleh WHO dan sudah sesuai. Hal ini seharusnya juga dilakukan oleh pihak pemerintah Indonesia dalam membatasi penerbangan guna mencegah penyebaran dan penularan virus. Namun untuk beberapa negara juga masih ada yang belum melaksanakan dan menerapkan rekomendasi dari WHO. Seperti ungkapan dari informan sebagai berikut :

"Seperti aturan WHO mengenai pembatasan penumpang dan penggunaan masker selama di dalam pesawat seharusnya dilakukan untuk proteksi terhadap virus Covid-19, Tetapi di beberapa penerbangan yang saya lakukan tidak ada pembatasan mengenai jumlah penumpang" (B1, 29 tahun, traveller ke Eropa dan Afrika).

Sedangkan tanggapan berbeda dari informan B2 (traveler ke Jepang) dan B3 (traveler ke Arab Saudi) mengenai penerapan kebijakan di negara yang pernah dikunjungi belum sepenuhnya terlaksanakan dengan maksimal.

"Kayaknya kemaren itu kalau belum terlalu. Hanya sudah ditetapkan kalau pusat perbelanjaan jam 8 sudah harus tutup. Contohnya pertokoanpertokoan di sekitar Shibuya itu jam 8 udah harus tutup. Jadinya ya mungkin itu saja ya yang saya lihat sebagai bentuk pencegahan ya" (B2, 35 tahun, traveller Jepang).

Adapun pendapat lain dari informan A1 (stakeholder) mengenai penerapan kebijakan rekomendasi WHO di Indonesia sudah diterapkan seperti adanya HAC namun belum sepenuhnya dilaksanakan secara maksimal karena terkait kendala Bahasa karena masih menggunakan Bahasa asing serta sistem.

\section{Kesesuaian Penerapan Travel Warning di Negara lain yang Dapat Diterapkan di Indonesia}

Menurut informan B1 (traveler ke Eropa), penerapan travel warning di negara lain seperti penerapan lockdown di Italia belum tepat diterapkan di Indonesia dilihat dari segi ekonomi dan penduduk. Sama halnya dengan informan B2 (traveler ke Jepang) yang berpendapat mengenai penerapan lockdown di Indonesia. Penduduk Indonesia yang banyak menyebabkan kebutuhan yang harus dipenuhi juga banyak dan ditambah lagi kondisi penduduk yang berbeda, sehingga jika dilakukan lockdown di Indonesia tidak dapat mencukupi

(C) Poltekkes Kemenkes Jakarta I

Jl. Wijaya Kusuma No. 47-48 Cilandak Jakarta Selatan, Indonesia email: jurnalquality@poltekkesjakarta1.ac.id kebutuhan penduduknya. Tingkat kepatuhan masyarakat Indonesia berbeda dengan tingkat kepatuhan masyarakat di negara lain, sehingga banyak penerapan kebijakan travel warning yang berhasil diterapkan di negara lain, namun tidak berhasil diterapkan di Indonesia.

"Untuk peraturan lockdown yang diterapkan di Italia, mungkin belum tepat dilakukan di Indonesia. karena Indonesia memiliki penduduk yang banyak, sehingga apabila diterapkan akan banyak kebutuhan dasar yang harus terpenuhi. Dan yang kita tau kekayaan negara yang kita punya itu budgetnya tidak cukup. Untuk aturan yang lain selama yang ku alami masih lebih ketat di Indonesia, mungkin karena aku warga negara Indonesia, dan selama melakukan perjalanan ke eropa belum bisa memahami semua aturan disana karena kendala bahasa juga" (B1, 29 tahun, traveller ke Eropa dan Afrika).

"Tidak ada ya karena beda kondisi ya antara Kita dan di Jepang. Karena memang kan orang di Jepang itu patuh-patuh ya dan tingkat kepatuhan kepada pemerintah nya sangat tinggi, rasa nasionalisme nya juga lebih tinggi, orangorang disana lebih aware ya dan juga lebih disiplin" (B2, 35 tahun, traveler ke Jepang).

Pendapat lain dari informan B3 (traveler Arab Saudi) mengenai penerapan kebijakan PSBB diharapkan dapat dilakukan secara maksimal.

"Mengenai PSBB , di sana betul-betul dilakukan, diharapkan di Indonesia juga bisa dipatuhi” (B3, 57 tahun, traveller ke Arab).

Adapun tanggapan lain dari informan A1 (stakeholder) sebaiknya penerapan PSBB di Indonesia lebih banyak disosialisasikan mulai dari tingkat aparatur yang paling rendah yaitu RT dan RW serta perlunya meningkatkan sosialisasi.

\section{Pembahasan}

Dalam penelitian ini, tim peneliti melakukan eksplorasi persepsi dan pengalaman informan mengenai travel warning serta bagaimana pemahaman dan kesesuaian dari kebijakan tersebut diberlakukan di setiap negara yang di datangi oleh informan. Travel warning merupakan istilah yang populer dikenal untuk menyebut kebijakan suatu negara untuk memberikan informasi yang memuat pertimbangan dan peringatan kepada warga 
negaranya yang akan bepergian ke luar negeri atau sedang berada di luar negeri. WHO mengeluarkan dokumen yang memberikan rekomendasi terbaru untuk lalu lintas internasional sehubungan dengan wabah Covid-19, mengingat situasi yang berkembang pesat dan menggantikan saran yang sudah diterbitkan pada 27 Januari 2020. Kebijakan tersebut berisi rekomendasi yang diberikan WHO untuk lalu lintas internasional, rekomendasi umum untuk semua negara, rekomendasi untuk berpergian internasional bagi traveler dan rekomendasi setibanya traveler di titik masuk suatu negara.

Travel Warning merupakan salah satu keputusan yang membutuhkan pemikiran yang matang dan analisa yang mendalam terhadap segala bentuk akibat dan dampak yang kemungkinan akan terjadi. Kebijakan Travel Warning di Indonesia melibatkan lintas sektor dan koordinasi berbagai pihak, tidak hanya Kementerian Kesehatan, namun juga melibatkan koordinasi dengan Kementrian Luar Negeri dan Kementerian Perhubungan. Kebijakan Travel Warning di Indonesia dibuat setelah menunggu Kebijakan Travel Warning atau rekomendasi yang dikeluarkan oleh WHO. Hal ini sejalan dengan penelitian I Made Budi (2018) yang menyatakan bahwa travel warning biasanya dikeluarkan oleh Kementerian Luar Negeri dan didasari oleh suatu kewenangan yang dimiliki dalam hal penetapan kebijakan sesuai dengan ketentuan peraturan perundang-undangan yang berlaku (Arsika, Jaya and Satyawati, 2018).

Berdasarkan penelitian ini, Indonesia sudah membuat Protokol Pintu Masuk Wilayah Indonesia (Bandara, Pelabuhan, PLBDN) yang sudah sesuai dengan Kebijakan Travel Warning yang dikeluarkan oleh WHO. Kemudian untuk pengaplikasiannya di lapangan, sudah sama baik itu di bandara, pelabuhan maupun PLBDN (Pos Lintas Batas Darat Negara) di kota mana pun di Indonesia.

Dari hasil studi ini ditemukan bahwa pemahaman informan mengenai Travel Warning ini sudah baik. WHO membuat merekomendasi umum untuk kebersihan pribadi, etiket batuk dan menjaga jarak setidaknya satu meter dari orang yang menunjukkan gejala tetap sangat penting bagi semua wisatawan. Selain itu, lakukan kebersihan tangan sesering mungkin, ketika batuk atau bersin tutupi hidung dan mulut anda dengan siku tertekuk atau kertas tisu dan segera buang tisu dan lakukan

(C) Poltekkes Kemenkes Jakarta I

Jl. Wijaya Kusuma No. 47-48 Cilandak Jakarta Selatan, Indonesia email: jurnalquality@poltekkesjakarta1.ac.id kebersihan tangan, jangan menyentuh mulut dan hidung dan penggunaan masker medis tidak diperlukan jika tidak menunjukkan gejala. Karena tidak ada bukti bahwa memakai topeng - dari jenis apa pun - melindungi orang yang tidak sakit.

Informan sudah paham dengan peraturan tersebut seperti menggunakan masker, jaga jarak (physical distancing), dan cuci tangan karena itu merupakan bagian dari perilaku hidup bersih dan sehat. Jika sedang mengalami demam sebaiknya tidak melakukan perjalanan dahulu. Tidak semua kebijakan dapat diaplikasikan di seluruh negara. Cuci tangan dan penggunaan masker bisa saja diterapkan di seluruh negara, tetapi untuk social distancing sepertinya sulit dilakukan di seluruh negara, contohnya seperti di Indonesia yang jumlah penduduknya banyak, penduduknya masih sulit untuk menghindari kerumunan karena kebutuhan perekonomian dan juga karena faktor ketidak pahaman.

Menurut Weber dan Hsee perbedaan budaya dapat berperan dalam risiko persepsi individu dalam memahami yang kemudian berdampak pada keputusan tujuan. Perbedaan signifikan dalam persepsi risiko, kecemasan, persepsi keamanan dan niat melakukan perjalanan di kalangan Traveler dari berbagai negara berbeda, hal ini mempengaruhi cara mereka memahami dan mempersepsikan kebijakan atau peraturan yang telah dibuat (Sonmez dan Graefe dalam Ahnsul, 2012), persepsi risiko atau masalah keselamatan sangat penting dalam pengambilan keputusan proses wisata karena dapat mengubah rasional pengambilan keputusan sebagai pertimbangan melakukan perjalanan dan mematuhi aturan yang ada. Oleh karena itu, penerapan Travel Warning yang dikeluarkan oleh WHO yang seharusnya diterapkan oleh semua negara di dunia, tidak diterapkan oleh beberapa negara karena adanya perbedaan budaya dalam memahami dan mempersepsikan sebuah aturan atau kebijakan (Garg, 2013).

Sejak awal Februari 2020, Indonesia juga mengeluarkan larangan bagi semua pendatang yang tiba dari China daratan atau mereka sudah berada di China daratan selama 14 hari untuk masuk dan transit di Indonesia. Selain itu, penghentian sementara fasilitas bebas visa dan visa on arrival bagi warga negara China. 
Dalam penelitian ini, para informan mendukung adanya karantina 14 hari. Selama masa karantina, kondisi tubuh pun harus dipantau menimbulkan gejala atau tidak, untuk menghindari penularan virus ke orang lain. Para informan pun melakukan karantina selama 14 hari setelah melakukan perjalanan ke luar negeri selama pandemi Covid-19 ini terjadi.

Dalam rekomendasi travel warning yang telah dibuat oleh WHO terus menyarankan agar penerapan pembatasan perjalanan atau perdagangan ke negara-negara yang mengalami wabah Covid-19. Diharapkan dengan adanya rekomendasi ini sebagai bentuk upaya pencegahan penyebaran Covid-19 yang lebih banyak lagi.

Pada penelitian ini kebijakan untuk pembatasan melakukan perjalanan memang perlu dilakukan karena bisa meningkatkan penyebaran virus Covid-19 ini menjadi lebih luas. Namun perlu dipertimbangkan karena ada beberapa daerah dari suatu negara merupakan tempat wisata yang akan terkena dampaknya yaitu dalam segi pendapatan atau perekonomian. Respon dari informan menanggapi mengenai lalu lintas keluar masuk internasional sudah sesuai dengan management of ill travel at point entry seperti guidelines dari WHO yang kemudian menjadi rekomendasi Travel Warning WHO. Ketika rekomendasi ini dikeluarkan oleh WHO, seluruh negara diwajibkan pada setiap pintu masuk seperti di bandara, pelabuhan dan daratan harus menerapkan rekomendasi Travel Warning WHO. Travel Warning ini tidak hanya diberlakukan pada traveler saja tapi juga berlaku pada semua crew atau pekerja pesawat atau kapal yang turut dalam perjalanan tersebut.

Pembatasan penumpang dan penggunaan masker selama bepergian sangat dianjurkan untuk dilakukan guna proteksi terhadap virus Covid-19. Namun informan mengaku beberapa penerbangan masih saja belum menerapkan pembatasan mengenai jumlah penumpang. Untuk penerbangan selain penumpang, seperti obat, makanan kosmetik dan alat kesehatan tetap diimport dan tidak ada pembatasan namun tetap ada karantina dalam lalu lintas internasional. Di beberapa negara tertentu, ada aturan yang tidak dapat dilakukan oleh negara tersebut seperti pembatasan impor dan ekspor. Seperti negara berkembang mungkin akan sulit juga

(C) Poltekkes Kemenkes Jakarta I

Jl. Wijaya Kusuma No. 47-48 Cilandak Jakarta Selatan, Indonesia email: jurnalquality@poltekkesjakarta1.ac.id melakukan pembatasan di bidang impor da ekspor mengingat risiko yang besar dari segi ekonomi.

Negara-negara harus mengintensifkan pengawasan untuk wabah dan memantau dengan hati-hati evolusi wabah Covid-19 serta memperkuat pengawasan epidemiologis. Negara-negara harus terus meningkatkan kesadaran melalui komunikasi risiko yang efektif mengenai Covid-19 kepada masyarakat umum, profesional kesehatan, dan pembuat kebijakan, dan untuk menghindari tindakan yang mempromosikan stigma atau diskriminasi. Negara-negara harus berbagi dengan WHO semua informasi rilevan yang diperlukan untuk menilai dan mengelola Covid-19 secara tepat waktu, sebagaimana disyaratkan oleh Peraturan Kesehatan Internasional Tahun 2005.

Sinkronisasi rekomendasi umum untuk semua negara dari WHO dengan yang sudah di aplikasikan di seluruh dunia sudah dirasakan dan ditanggapi oleh beberapa informan. Seperti pengaplikasian Health Alert Card (HAC) dari WHO sudah diberlakukan diseluruh pintu masuk negara di dunia untuk diisi oleh seluruh traveler yang melakukan perjalanan. Sarana dan prasarana lainnya seperti APD, ruang pemeriksaan, lembar anamnesa, alat deteksi dini juga sudah sesuai dan sudah diterapkan sesuai dengan anjuran dari WHO.

Selain sarana dan prasarana, sinkronisasi rekomendasi dari WHO untuk penginapan atau hotel yang mungkin ditempati oleh traveler yang berkunjung ke negara-negara selama masa pandemi juga sudah sesuai. Informan yang berangkat ke Eropa mengatakan bahwa di penginapan, berkomunikasi dengan resepsionisnya hanya melalui email, tidak bertemu secara langsung, hal ini sebagai upaya menerapkan rekomendasi dari WHO. Sinkronisasi rekomendasi WHO juga sudah diterapkan pada trasnportasi di beberapa negara dengan memberlakukan physical distancing di tempat-tempat atau kendaraan umum. Hal ini sejalan dengan penelitian (Shama Nazneen, 2020) yang menyatakan pandemi telah membuat publik lebih memperhatikan kebersihan dan keselamatan. Hasil deskriptif penelitian menunjukkan bahwa responden lebih peduli tentang kebersihan dan keselamatan masyarakat transportasi, situs rekreasi, dan hotel. Itu menandakan persepsi keselamatan dan kebersihan akan menjadi faktor penting dalam keputusan perjalanan. Karena itu, untuk meningkatkan kembali

ISSN 2655-2434 
pasokan pariwisata dan menuntut organisasi terkait, termasuk pemerintah dan swasta, harus memastikan keselamatan dan kebersihan tempat turis, hotel dan restoran dan dalam transportasi umum (Nazneen, Hong and Ud Din, 2020).

Setibanya traveler di titik masuk suatu negara, skrining suhu di titik masuk suatu negara mungkin tidak terlalu efektif karena kita bisa saja melewatkan pelancong yang masih berada dalam masa inkubasi penyakit atau pelancong yang menyembunyikan demam selama perjalanan atau mungkin adanya demam dari penyebab yang berbeda. Oleh karena itu, disarankan untuk menyertai dengan: pesan kesehatan, kuesioner primer, pengumpulan dan analisis data, kasus yang dicurigai terdeteksi pada saat kedatangan, personel terlatih untuk deteksi dini dan evaluasi awal kasus dan dilengkapi dengan persediaan yang diperlukan.

Sinkronisasinya di Indonesia, Kemenkes sudah mengeluarkan protokol pintu masuk wilayah Indonesia yang merupakan aturan untuk mencegah tangkal di pintu masuk negara

(bandara, pelabuhan dan PLBDN). Protokol pintu masuk wilayah Indonesia mencakup aspek seperti deteksi dini perlaku perjalanan yang diduga sakit, wawancara dan anamnesis pelaku perjalanan yang sakit, pelaporan kasus pelaku perjalanan yang diduga terjangkit Covid-19,dan tindakan kekarantinaan kesehatan.

Menurut hasil penelitian ini, skrinning yang dilakukan di bandara, pelabuhan dan daratan di Indonesia sudah sesuai dengan protokol guideline travel warning dari WHO. Di setiap bandara dan pelabuhan yaitu mengisi form atau HAC (Health Alert Card), pemeriksaan kesehatan seperti suhu badan, menyediakan hand sanitizer dan sudah di sediakan tempat isolasi apabila ada penumpang yang terkena kasus.

Pada penelitian ini, masih banyak masyarakat yang masih belum patuh dan masih cuek dalam aturan PSBB. Hal ini disebabkan karena tuntutan pemenuhan kebutuhan pada masyarakat untuk bekerja dan banyak masyarakat yang sudah bosan di dalam rumah. Hal ini diperlukan ketegasan dan konsistensi pemerintah dalam kebijakan yang di buat, seperti memberi sanksi kepada masyarakat yang melanggar sehingga PSBB tidak hanya sekedar himbauan saja. Selain itu, setiap orang berkewajiban ikut serta dalam penyelanggaraan kekarantinaan

(C) Poltekkes Kemenkes Jakarta I

Jl. Wijaya Kusuma No. 47-48 Cilandak Jakarta Selatan, Indonesia email: jurnalquality@poltekkesjakarta1.ac.id kesehatan. Karena aturan PSBB ini masih memperbolehkan pebisnis untuk terbang untuk melakukan perjalanan ke luar kota atau ke luar negeri.

Upaya pemerintah dalam mengantisipasi perkembangan virus corona saat ini cukup membuat khawatir masyarakat.Bukan hanya khawatir terjangkit virus corona saja, tetapi kebijakan pemerintah daerah yang memberlakukan PSBB untuk beberapa wilayah. Karena hal ini akan menyulitkan masyarakat dalam melakukan kegiatan dan mobilitasnya. Hal ini walaupun berisiko besar, tetapi harus dilakukan guna menghentikan penyebaran virus corona tersebut. PSBB sebenarnya adalah perluasan dari social distancing, yang mencangkup wilayah tertentu. Tidak heran dalam beberapa pemberitaan, kebijakan PSBB menjadi bahan pertimbangan beberapa pejabat daerah setempat. Yang menjadi pertimbangan tersebut adalah berdasarkan kesiapan anggaran dan dampak sosial yang timbul (Yunus and Rezki, 2020).

Sulit menerapkan kebijakan PSBB bagi suatu komunitas sosial saat ini. Karena manusia tidak pernah berhenti melakukan mobilitas dan kegiatan bergeraknya dari satu tempat ke tempat lain. Oleh karenanya, keberhasilan implementasi kebijakan ini membutuhkan keterlibatan stakeholder secaara demokratis dan partisipatif. Stakeholder dan pembuat kebijakan harus terus menerus terlibat dalam dialog untuk menganalisis konsekuensi dari pelaksanaan kebijakan tersebut.

Travel warning yang sudah diterapkan diberbagai negara guna mencegah penyebaran Covid-19 menimbulkan paradigma yang berbeda bagi setiap traveler. Sebelumnya sesuai dengan surat keputusan yang dikeluarkan oleh WHO, mengenai himbauan pembatasan perjalanan lintas internasional bagi seluruh negara yang terkena dampak pandemic belum sepenuhnya diterapkan oleh masing-masing negara. Di Eropa, penerapan travel warning sudah mulai diterapkan di beberapa kota misalnya skrinning awal saat kedatangan traveler di bandara. Namun, fasilitas umum seperti restoran dan tempat hiburan masih dipadati oleh pengunjung. Sedangkan di Jepang, sudah dilakukan penutupan tempat hiburan dan sekolah. Berbeda dengan halnya di Arab Saudi yang mengeluarkan kebijakan mengenai larangan keluar kota.

ISSN 2655-2434 


\section{Kesimpulan dan Saran}

Berdasarkan informasi yang dikumpulkan dari informan baik traveler maupun Stakeholder, semuanya memiliki persepsi yang sama. Secara keseluruhan, kebijakan dianggap sangat penting guna mencegah dan mengurangi penyebaran serta penularan virus. Kebijakan travel warning merupakan implementabsi dari kewajiban negara untuk melindungi masyarakat dari penyebaran Covid-19, termasuk ketika mereka berada di luar negeri. Kebijakan Travel Warning yang di keluarkan oleh negara lain menunjukkan variasi yan relatif beragam, terutama berkaitan dengan identifikasi risiko dan lembaga yang berwenang untuk menyampaikan imbauan perjalanan. Karena itu tidak semua kebijakan dapat diaplikasikan di seluruh negara. Cuci tangan dan penggunaan masker bisa saja diterapkan di seluruh negara, tetapi untuk social distancing sepertinya sulit dilakukan di seluruh negara, contohnya seperti di Indonesia yang jumlah penduduknya banyak, penduduknya masih sulit untuk menghindari kerumunan karena kebutuhan perekonomian dan juga karena faktor ketidak pahaman.

Hasil implementasi kebijakan mengenai protokol pintu masuk wilayah Indonesia yang dikeluarkan oleh KKP telah berjalan cukup baik dan sudah sesuai dengan panduan dari travel Warning WHO. Namun pada pelaksanaannya tidak semua bandara melakukan skrining. Untuk skrining tubuh sebaiknya tetap dilakukan walaupun tidak semua orang yang terkena Covid mengalami demam, tetapi setidaknya sudah melakukan penapisan pertama. Diharapkan skrining ini dapat dilakukan di seluruh bandara, dan akan lebih baik untuk dilakukan penutupan bandara sementara waktu untuk menghindari penyebaran Covid-19 ini lebih luas karena beberapa penderita Covid 19 ini tidak memiliki gejala.

Implementasi kebijakan perlu dimaksimalkan dengan menghilangkan faktor-faktor kendala implementasi dengan melaksanakan sosialisasi yang lebih intens tentang aspek penyakit, kesadaran hukum terhadap produk kebijakan , pemenuhan biaya operasional petugas, dan sensitifitas petugas medis maupun seluruh unsur

(C) Poltekkes Kemenkes Jakarta I

Jl. Wijaya Kusuma No. 47-48 Cilandak Jakarta Selatan, Indonesia email: jurnalquality@poltekkesjakarta1.ac.id masyarakat untuk bersama-sama megendalikan virus ini.

Semua struktur pemerintahanan diharapkan dapat terlibat dalam menjalankan kebijakan ini. Bukan hanya satu atau dua sektor tetapi seluruh sektor, dan bukan hanya pemerintah pusat tetapi juga sampai ke sistem pemerintahan paling bawah. Selanjutnya diharapkan semua sektor satu suara, tidak memiliki kebijakan yang berbeda-beda dalam menerapkan kebijakan ini.

\section{Daftar singkatan}

ACI (Airport Council International), APD (Alat Perlindung Diri), COVID-19 (Corona Virus Disease 2019), HAC (Health Alert Card), IATA (International Air Transport Association), KKP (Kantor Kesehatan Pelabuhan), PLBDN (Pos Lintas Batas Negara), PSBB (Pembatasan Sosial Berskala Besar), WD (Wawancara Mendalam), WHO (World Health Organization)

\section{Daftar Pustaka}

Aditya, M. (2020). Virus Corona Dan Dampaknya Terhadap Industri Pariwisata. Retrieved April 3, 2020, from https://www.bobobox.co.id/blog/dampakvirus-corona-pada-pariwisata/

Anzai, A. (2020). Assessing The Impact of Reduced Travel On Exportation Dynamics of Novel Coronavirus Infection (COVID-19). Journal of Clinical Medicine, 9(2). From: https://www.ncbi.nlm.nih.gov/pmc/articles/ PMC7073579/

Arsika, I. M. (2018). Kebijakan Travel Warning dan Pembatasan Hak Berwisata. Pandecta, Volume 13(No. 1), page 24-36. From: https://www.researchgate.net/publication/3 35656037_Kebijakan_Travel_Warning_da n Pembatasan Hak Berwisata

Chinazzi, M. (2020). The Effect of Travel Restriction On The Spread of The 2019 Novel Coronavirus (COVID-19) Outbreak. Science (New York, N.Y.), 9757 (March), pp.

ISSN 2655-2434 
$1-2$.

From:

https://pubmed.ncbi.nlm.nih.gov/32144116

I

Jessiman, P. E., Campbell, R., Jago, R., Van Sluijs, E. M. F., \& Newbury-Birch, D. (2019). A qualitative study of health promotion in academy schools in England. BMC Public Health, 19(1), 1-13. https://doi.org/10.1186/s12889-019-7510-x. from:https://bmcpublichealth.biomedcentral.c om/articles/10.1186/s12889-019-7510-x

Jordan (2017) 'Kerangka Analisis Kebijakan Perencanaan Pendidikan', Journal of Chemical Information and Modeling, 53(9), pp. 16891699. Available from: https://www.academia.edu/38131157/KERAN GKA_ANALISIS_KEBIJAKAN_PENDIDIK $\underline{\mathrm{AN}}$

Kemkes.(2020) 'Usulan PSBB dalam Permenkes No 9 Tahun 2020' Published on 4 April 2020. Available from: http://p2p.kemkes.go.id/usulan-psbb-bisajadi-solusi-covid-19-permenkes-no-9-aturtata-caranya/

LIPI. (2020). Dampak Virus Corona Pada Laju Ekonomi Indonesia 2020. Retrieved Februari 2020, 25, from http://lipi.go.id/siaranpress/Dampak-VirusCorona-pada-Laju-Ekonomi-Indonesia$\underline{2020 / 21963}$

Rothan, H. A. (2020). The Epidemiology and Pathogenesis of Coronavirus Disease (COVID-19) Outbreak. Journal of Autoimmunity. Elsevier, (February), $p$. 102433. doi: 10.1016/j.jaut.2020.102433. Available from: https://www.sciencedirect.com/science/arti cle/pii/S0896841120300469

Sohrabi, C. (2020). World Health Organization declares global emergency: A review of the 2019 novel coronavirus (COVID-19). International Journal of Surgery. Elsevier, 76(February), pp. 71-76. doi: 10.1016/j.ijsu.2020.02.034. Available from:

(C) Poltekkes Kemenkes Jakarta I

Jl. Wijaya Kusuma No. 47-48 Cilandak Jakarta Selatan, Indonesia email: jurnalquality@poltekkesjakarta1.ac.id https://www.sciencedirect.com/science/arti cle/pii/S1743919120301977

Susilo, A. (2020). Coronavirus Disease 2019: Tinjauan Literatur Terkini. Jurnal Penyakit Dalam Indonesia, Vol. 7, No. 1, 45. Available from: http://jurnalpenyakitdalam.ui.ac.id/index.ph p/jpdi/article/view/415

WHO. (2020). Joint ICAO-WHO Statement on COVID-19. Retrieved 11 March 2020 from: https://www.who.int/news-room/articlesdetail/joint-icao-who-statement-on-covid$\underline{19}$

WHO. (2020). Key Considerations For Repatriation And Quarantine of Travellers In Relation To The Outbreak of Novel Coronavirus 2019nCoV. World Health Organization. Available from: https://www.who.int/newsroom/articles-detail/key-considerations-forrepatriation-and-quarantine-of-travellersin-relation-to-the-outbreak-of-novelcoronavirus-2019-ncov

WHO. (2020). Updated WHO Recommendations For International Traffis In Relation To COVID-19 Outbreak. Retrieved from https://www.who.int/news-room/articlesdetail/updated-who-recommendations-forinternational-traffic-in-relation-to-covid$\underline{19-o u t b r e a k}$

WHO. (2020). WHO Director-General's opening remarks at the media briefing on COVID19. Retrieved 11 March 2020 from https://www.who.int/dg/speeches/detail/wh o-director-general-s-opening-remarks-atthe-media-briefing-on-covid-19---11$\underline{\text { march- }}$

WMA, \& World Medical Association. (2013). WMA DECLARATION OF HELSINKIETHICAL PRINCIPLES FOR Scientific Requirements and Research Protocols. World Medical Association, June 1964, 2932.

Yunus, N. R. and Rezki, A. (2020) 'Kebijakan Pemberlakuan Lock Down Sebagai Antisipasi ISSN 2655-2434

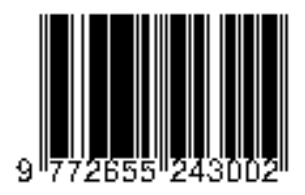


Penyebaran Corona Virus Covid-19', SALAM:

Jurnal Sosial dan Budaya Syar-i, 7(3). doi: 10.15408/sjsbs.v7i3.15083. Available from: https://www.who.int/news-room/articlesdetail/key-considerations-for-repatriation-andquarantine-of-travellers-in-relation-to-theoutbreak-of-novel-coronavirus-2019-ncov 